\title{
KÊTÊG
}

Jurnal Pengetahuan, Pemikiran dan Kajian Tentang Bunyi

Vol. 21., No. 2, November 2021, hal. 186-198

ISSN 1412-2065, eISSN 2714-6367

https://jurnal.isi-ska.ac.id/index.php/keteg

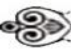

\section{FUNGSI RITUAL GENDHING TOLAK BALAK PADA PERTUNJUKAN JARANAN KRIDHA BUDAYA DI KABUPATEN TRENGGALEK}

\author{
Rika Wahyuningtyas \\ Jurusan Karawitan, \\ Institut Seni Indonesia Surakarta, \\ J1. Ki Hadjar Dewantara No 19 Kentingan, \\ Jebres, Surakarta (57126), Jawa Tengah, \\ Indonesia \\ rikawahyuningtyas71@gmail.com
}

\author{
Muhammad Nur Salim* \\ Jurusan Karawitan, \\ Institut Seni Indonesia Surakarta, \\ Jl. Ki Hadjar Dewantara No 19 Kentingan, \\ Jebres, Surakarta (57126), Jawa Tengah, \\ Indonesia \\ denmassalim88@gmail.com
}

dikirim 20 Februari 2022; diterima 24 Februari 2022; diterbitkan 01 Maret 2022

\begin{abstract}
Abstrak
Penelitian berawal dari ketertarikan mengenai fenomena ritual di dalam pertunjukan Jaranan Kridha Budaya. Ritual Tolak Balak diartikan sebagai sarana untuk menyampaikan pesan khusus kepada Tuhan Yang Maha Esa agar tidak menurunkan musibah, seperti bencana alam dan wabah penyakit. Pada sajian Ritual Obong Dupa disyaratkan menggunakan Gendhing Tolak Balak yang merupakan gending wajib dan tidak boleh diganti dengan gending lain. Gendhing Tolak Balak adalah sebuah gending diyakini memiliki fungsi ritual keagamaan pada Kesenian Jaranan Kridha Budaya saat sajian Ritual Obong Dupa. Gendhing Tolak Balak digunakan sebagai gending baku yang dimaknai sebagai sarana untuk menyampaikan permohonan, ataupun sebagai bentuk interaksi yang dilakukan secara tidak langsung kepada Tuhan dan danyang penunggu suatu tempat. Hubungan antara komponen gending dan ritual, menimbulkan sebuah kesan sakral dan memberikan pengaruh bagi pelaku dan masyarakat pendukungnya.
\end{abstract}

Kata Kunci: Fungsi, Ritual, Gendhing, Tolak Balak

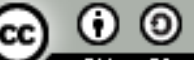

This work is licensed under a Creative Commons Attribution-ShareAlike 4.0

\begin{abstract}
The research started from an interest in ritual phenomena in the Jaranan Kridha Budaya performance. The Ritual of Rejection is defined as a means to convey a special message to God Almighty so as not to bring down calamities, such as natural disasters and disease outbreaks. In the Obong Incense ritual, it is required to use the Reject Balak Gendhing which is a mandatory gending and cannot be replaced with another gending. Gendhing Tolak Balak is a gending that is believed to have a religious ritual function in the Art of Jaranan Kridha Budaya when the Obong Incense Ritual is served. Gendhing Tolak Balak is used as a standard gending which is interpreted as a means to submit a request, or as a form of indirect interaction with God and the dancers of a place. The relationship between the components of gending and ritual, creates a sacred impression and influences the actors and their supporting communities.
\end{abstract}

Keywords: Funtion, Ritual, Gendhing, Tolak Balak,

\section{Pendahuluan}

Kesenian Jaranan Kridha Budaya adalah salah satu kelompok kesenian tumbuh dan berkembang di Desa Munjungan, Kecamatan Munjungan, Kabupaten Trenggalek. Kelompok

\footnotetext{
${ }^{*}$ Penulis Korespondensi
} 
jaranan Kridha Budaya didirikan pada tahun 2014 dan masih berkembang hingga sekarang. Perkembangan pada bentuk kesenian sebagai ekspresi perasaan manusia ini disebabkan karena penyesuaian terhadap perkembangan kehidupan manusia dan lingkungannya (Keesing 1981; Soemaryatmi 2012, 27). Indikasi perkembangan bentuk ini dapat dilihat pada setiap pementasan, berupa penyajian dengan nuansa berbeda yakni menampilkan kreasi garap tarian dan gending baik secara konsep sajian dan garap. Faktor utama perkembangan Kesenian Jaranan Kridha Budaya adalah bentuk hasil kerjasama antara penggarap tari dan karawitan. Kreasi garap menimbulkan kesan tidak monoton dan penonton tidak merasa bosan.

Terlepas dari progresivitas bentuk pertunjukan Jaranan Kridha Budaya, masyarakat pendukung masih memiliki kepercayaan terhadap makhluk gaib atau kekuatan roh yang hadir di dalam pertunjukan. Pengendalian kekuatan-kekuatan roh memerlukan suatu upacara ritual, dengan memohon berkah kepada Yang Maha Kuasa sekaligus meminta supaya kekuatan roh jahat tidak mengganggu. (Agustina and Salim 2020, 15) Kepercayaan ini yang kenudian dimanifestasikan ke dalam bentuk ritual dan ekspresi seni di masyarkat pendukungnya. (Sumardjo 2006, 177) Upacara ritual merupakan fenomena sosial yang dibangun melalui adanya interaksi sosial. (Turner 1969) Pada sajian pertunjukan Jaranan Kridha Budaya terdapat ritual khusus yang masih dilakukan oleh masyarakat pendukungya. Ritual ini masih dipegang erat masyarakatnya sebagai tradisi dengan tidak merubah elemen yang menyertainya meliputi waktu, tempat dan sesaji yang digunakan, meskipun terdapat penambahan unsur pendukung untuk menambah semarak dengan tanpa mengurangi kadar kesakralannya. (Fitriasari et al. 2012, 27-28) Ritual yang dilakukan di dalam pertunjukan Jaranan Kridha Budaya memiliki susunan yang runtut berdasarkan 'kesepakatan' antara pelaku kesenian dengan makhluk gaib yang dipercaya. Upacara ritual memiliki hubungan dengan unsur-unsur pembangunnya, meliputi tempat upacara, waktu upacara, benda-benda dan alat-alat upacara, dan orang-orang yang melakukan dan memimpin upacara. (Koentjaraningrat 1990)

Pertunjukan Jaranan Kridha Budaya diawali dengan pembacaan doa oleh para gambuh. Gambuh dalam kesenian jaranan dipercayai sebagai media interaksi antara manusia dengan gaib. Pembacaan doa dari gambuh dilakukan dengan melakukan perantara pembakaran dupa atau disebut dengan obong dupa. Ritual Obong dupa dilakukan sebelum awal pergelaran kesenian jaranan. Ritual Obong Dupa bertujuan untuk berdoa kepada Tuhan Yang Maha Esa agar diberi keselamatan dari awal acara hingga akhir acara. Pada sajian Ritual Obong Dupa terdapat sajian gending wajib atau gending inti. Gending adalah Lancaran Tolak Balak Pelog Nem atau lebih dikenal dengan lancaran Obong Dupa. Gendhing Tolak Balak tidak terlepas dari kandungan makna. Tolak diartikan sebagai menolak, menghilangkan, menghindari atau memusnahkan. Balak diartikan sebagai musibah, marabahaya dapat berupa penyakit, kekeringan dan gagal panen. Ritual Tolak Balak upaya untuk menyingkirkan marabahaya atau musibah pada kesenian Jaranan Kridha Budaya, ini didasarkan pada kepercayaan kepada gaib dapat mendatangkan manfaat dan musibah. Tolak Balak menjadi kebutuhan spiritual masyarakat. Ritual Tolak Balak diartikan sebagai sarana untuk menyampaikan pesan khusus kepada Tuhan Yang Maha Esa agar tidak menurunkan musibah, seperti bencana alam dan wabah penyakit. Pada sajian Ritual Obong Dupa disyaratkan menggunakan Gendhing Tolak Balak. Gendhing Tolak Balak adalah Gendhing wajib dalam kesenian Jaranan Kridha Budaya. Seniman Jaranan se-Karesidenan Kediri merancang Gendhing Tolak Balak dengan pemilihan nada-nada pendukung dan memasukkan sejarah Tolak Balak ke dalam cakepan Gendhing Tolak Balak. Melalui indikator-indikator tersebut dapat dilihat bahwa musik atau gending 
memiliki keterkaitan di dalam ritual Obong Dupa. Terkait dengan hal tersebut, di sini musik memiliki fungsi ritual seperti yang dikemukakan oleh Merriam. (Merriam 1964, 224) Penelitian ini secara khusus melihat hubungan antara ritual obong dupa dan Gendhing Tolak Balak di dalam konteks pertunjukan Jaranan Kridha Budaya di Trenggalek.

\section{Metode}

Penelitian ini menggunakan metode kualatatif untuk melihat fennomena gending di dalam suatu ruang lingkup pertunjukan jaranan secara menyeluruh. Melalui metode kualitatif, peneliti melihat hal-hal bersifat kompleks yang terkait dengan persepsi, motivasi, tindakan dan lain-lain, yang kemudian dideskripsikan sesuai dengan latar alamiahnya secara ilmiah. (Moleong 2014, 6) Melalui metode kualititaf peneliti juga hendak mengungkapkan fakta suatu kejadian, obyek, aktivitas, proses dan manusia secara apa adanya. (Prastowo 2011, 203)

Dalam penelitian ini pendekatan yang sesuai dengan konteks alamiah adalah etnografis. Pendekatan tersebut bertujuan untuk memahami hal yang dilihat dan didengarkan untuk menyimpulkan hal yang diketahui orang melalui tiga sumber, yaitu: (1) dari hal yang dikatakan orang, (2) dari cara orang bertindak, dan (3) dari berbagai artefak yang digunakan orang. (Spradley 2007, 9-10) Langkah-langkah yang dilakukan di dalam penelitian secara garis besar terbagi atas 3 tahapan, yakni tahap pengumpulan data, tahap analisis data dan tahap penyajian analisis data. Proses pada penelitian ini dibagi menjadi 3 tahapan: (1) pengumpulan data; (2) analisis data; (3) metode penyajian analisis data. (Ratna 2010, 84)

Pada tahap pengumpulan data lebih ditekankan pada data lapangan yang bersumber dari masyarakat kesenian Jaranan Kridha Budaya. Dengan prioritas objek yang bersumber dalam kehidupan masyarakat, maka di antara dua metode pengumpulan data yaitu pengumpulan data lapangan dan data pustaka, data lapangan dianggap lebih penting. Dengan adanya interaksi langsung dalam proses komunikasi data lapangan dengan sendirinya menyediakan informasi yang jauh lebih kaya. (Ratna 2010, 188-89)

\section{Pembahasan}

\section{A. Bentuk Pertunjukan Jaranan Kridha Budaya}

Pertunjukan dianggap sebagai manifestasi tindakan manusia dalam bentuk ritual, permainan, olah raga, hiburan populer, seni pertunjukan dan pertunjukan kehidupan sehari-hari. (Schechner 2002, 2) Pertunjukan Jaranan Kridha Budaya tumbuh dan berkembang di Desa Munjungan Kecamatan Munjungan Kabupaten Trenggalek. Jaranan Kridha Budaya adalah bentuk adopsi budaya dari Kesenian Jaranan Turonggo Yakso. Kesenian Jaranan Turonggo Yakso adalah bentuk kesenian rakyat di Desa Dongko sebagai wujud budaya hasil aktivitas, perbuatan dan karya manusia. Kesenian Jaranan Turangga Yakso dibentuk pada tahun 1980 dan masih eksis sampai sekarang. Jaranan Turonggo Yakso menjadi ikon wisata di Kabupaten Trenggalek. Jaranan Turonggo Yakso adalah kesenian rakyat bertemakan keprajuritan. Alur cerita Kesenian Jaranan Turonggo Yakso bersumber dari Upacara Baritan dengan wujud penggambaran sebuah tarian kelompok, penari Jaranan bertarung melawan celengan dan Barongan sebagai pengganggu hewan peliharaan Dadungawuk yang digambarkan sebagai seorang penunggang kuda saat menunggang properti jaranan berhiaskan gambar raksasa. 
Tahapan-tahapan pada alur cerita Kesenian Jaranan Turonggo Yakso, kesenian Jaranan Kridha Budaya tersaji atas beberapa bagian. Bagian awal adalah bagian pertama pada kesenian Jaranan Kridha Budaya. Bagian awal ditandai dengan para penari keluar menuju panggung sesuai dengan karakter penari. Peran penari terbagi menjadi penari wanita dan pria, masing-masing sejumlah enam orang dengan menggunakan atribut jaranan buto, sebagai gambaran hewan ternak. Penari pria sejumlah dua orang dengan menggunakan atribut celengan, digambarkan sebagai hewan pengganggu. Penari menggunakan atribut buto dengan wajah menyeramkan, digambarkan sebagai buto raksasa dipercayai masyarakat menyebabkan marabahaya di desa.

Pada bagian tengah, konflik sudah mulai muncul. Konflik disebabkan oleh celengan masuk dan mengganggu pada pertengahan tarian jaranan. Cerita bermula pada saat Dhadhung Awuk menjaga hewan ternak, tiba-tiba muncul seekor celeng atau babi. Babi mengganggu hewan ternak milik Dhadhung Awuk, kemudian terjadi perkelahian antara celeng dan jaranan milik Dhadhung Awuk. Peperangan ditandai dengan jaranan bersatu dan membuat strategi untuk melawan celengan. Perjuangan mereka membuahkan hasil atas kerjasama jaranan. Celengan kalah dan melarikan diri.

Bagian akhir adalah puncak dari permasalahan. Keberhasilan mengalahkan celengan digambarkan dengan penari jaranan dihadapakan kembali dengan masalah lebih besar, yaitu Buto berbadan besar dan menyeramkan. Kariman menjelaskan, jaranan Dhadhung Awuk berhasil mengalahkan celengan, muncul masalah baru dan lebih besar, yaitu berhadapan dengan Buto raksasa berwajah seram. Buto menyebarkan hama untuk petani dan penyakit untuk hewan ternak dan manusia. Peperangan menyebabkan jaranan kewalahan dan hampir menyerah. Mengetahui kekalahan, Dhadhung Awuk menggantikan posisi jararan. Pertarungan itu berjalan 40 hari 40 malam, setelah sampai pada titik lemahnya, Barongan menyerah dan melarikan diri.

\section{B. Ritual Obong Dupa}

Ritual sebagai sebuah tindakan 'peribadahan' berupa ekspresi simbolik yang terbangun atas bahasa gerak serta pemikiran religius. perilaku ini kemudian menjadi keajaiban permanen (sakral) yang dijalankan secara terus menerus oleh masyarakat yang meyakininya. (Koentjaraningrat 1997, 81) Ritual Obong Dupa dalam Kesenian Jaranan Kridha Budaya adalah praktik ritual diyakini sebagai media interaksi pelaku kesenian dengan ruh leluhur, dengan tujuan menjalin hubungan baik dengan mereka. Tradisi masyarakat adalah suatu upaya masyarakat untuk menjaga dan menciptakan keseimbangan sistem dalam sebuah komunitas dan lingkungan alam sekitar. Secara organisasi kebiasaan seperti adat istiadat, norma-norma dan nilai-nilai yang dianut oleh masyarakat adalah suatu katalisator untuk memelihara keseimbangan sistem sosial dan kebudayaan masyarakat.

Ritual didasarkan atas struktur pelaksanaan dari awal hingga akhir yang di dalamnya memuat rangkaian-rangkaian aktivitas. (Geertz 1992, 32) Pada Ritual Obong Dupa terdapat tahapan-tahapan wajib ditempuh oleh pelaku kesenian. Sajian ritual Obong Dupa, para tetua berkumpul di tempat penyelenggaraan dengan duduk melingkari sesajen, meliputi beras ketan, pisang raja, kembang telon, kambil gothil. Awal dimulai proses ritual adalah dengan tradisi kebatinan kejawen. Proses ini diawali dengan cara memusatkan perhatian dan melupakan dunia melalui semedi. Para gambuh duduk bersila dengan menundukkan pandangan selayaknya seorang yang tengah memohon. Masing-masing dari mereka membawa sebuah Kendil berisi bunga telon, bara api, kemenyan dan minyak fanbo. Salah satu uba rampe terperan penting dalam prosesi ritual 
adalah kemenyan. Endraswara menjelaskan, memang diakui bahwa simbol tumbal spiritual tadi mengandung pengaruh sinkretik Hindu-Jawa dan Islam-Jawa, yang menyatu padu dalam wacana kultural mistik meyakini bahwa dengan membakar kemenyan pada saat ritual mistik adalah perwujudan persembahan kepada Tuhan. Kukus (asap) dupa dari kemenyan yang membumbung ke atas, tegak lurus, tidak mobat-mabit ke kanan kiri adalah tanda bahwa sesajinya diterima (Endraswara 2003, 196)

Tetua membaca mantra-mantra berisi permohonan kepada Tuhan agar diberikan perlindungan selama pertunjukan berlangsung. Semedi dapat diartikan sebagai sarana ibadah. Seseorang mampu berkomunikasi dan berinteraksi dengan roh gaib. Dengan mengosongkan segala pikiran dari unsur keduniawian, tetua bisa menikmati, memandang dan merasakan. Semedi digunakan sebagai sesembahan kepada para danyang penunggu tempat untuk memohon izin atau uluk salam sebatas menggunakan tempat singgahan. Tetua meyakini, segala tempat ada penunggu, baik mempunyai sifat baik maupun sifat buruk. Mereka menganggap danyang seperti seorang manusia sedang menerima tamu. Tempat singgahan para danyang diartikan sebagai rumah, dan selebihnya sebuah rumah memerlukan bahan pangan. Bahan pangan diartikan sebagai sesajen yang telah disiapkan sebagai sarat izin menempati daerah.

Setelah melakukan upacara semedi, para tetua meletakkan kembali Kendil, kemudian salah satu gambuh berdiri dengan membawa garam dan menaburkan ke seluruh penjuru panggung. Garam diartikan sebagai pagar atau penolak mara bahaya atau dalam masalah lain, garam difungsikan sebagai jalan atau penunjuk arah dalam dunia gaib. Peran garam dalam Kesenian Jaranan Kridha Budaya sangat penting. Garam berfungsi sebagai media untuk penyaluran energi, membuang sial dan media pembersihan diri. Dalam Kesenian Jaranan Kridha Budaya, garam direalisasikan sebagai sarana penolak bahaya atau gangguan dari manusia maupun roh gaib dan sebagai penunjuk arah kepada para danyang

Kesenian Jaranan tidak terlepas dari penggunaan atribut, diantaranya, aribut jaran kepang, pecut, barongan dan celengan. Pada prosesi Ritual Obong Dupa, semua atribut dikumpulkan menjadi satu di tengah-tengah panggung. Salah diantara gambuh atau pawang mengambil pecut khusus. Pecut khusus berbeda dengan pecut jaranan pada umumnya. Pecut memiliki ukuran lebih besar dan berat. Sebelum digunakan, pecut melalui proses ritual. Pada malam Jum'at, pecut disucikan di sungai tempuran, yaitu tempat bertemunya sungai dari segala penjuru. Fenomena menunjukkan di dalam pecut telah terdapat roh penunggu dan untuk menjalin interaksi baik dengan roh , maka pelaku kesenian diwajibkan untuk melakukan penyucian. Pecut dibungkus dengan kain mori atau biasa disebut kain kafan. Prosesi Ritual Obong Dupa, setelah dibuka dari kain penutup, pecut dihempaskan ke udara menuju sisi-sisi panggung dan menghasilkan suara keras. Secara analogi, suara pecut diisyaratkan sebagai suara petir menggelegar. Kariman menyakini, pecut difungsikan sebagai penanda acara jaranan segera dimulai dan pengundang roh gaib. Suara pecutan menandakan bahwa pertunjukan akan segera dimulai dan mempersilahkan roh gaib untuk turut hadir di acara .

Setelah para tetua merasakan kehadiran roh gaib ke tengah pertunjukan, gambuh kemudian memberikan tempat kepada mereka, meliputi atribut jaran kepang, pecut, barongan, celengan dan alat musik kendang, gong, dan slompret. Roh pengisi atribut, beda dengan roh gaib yang datang sebagai tamu. Jamuan diberikan kepada roh tamu meliputi sesajen, seperti kembang telon, ayam lodho, kemenyan, kelapa, ubarampe takir dan pisang raja. Jamuan ini berfungsi sebagai ungkapan 
rasa terimakasih kepada roh gaib karena telah berkenan hadir pada pertunjukan kesenian Jaranan Kridha Budaya.

Komponen terpenting dalam terselenggaranya pertunjukan adalah sesajen. Sesajen dalam kesenian Jaranan Kridha Budaya diartikan sebagai jamuan atau seserahan untuk para danyang atau penunggu suatu tempat, guna untuk memohon agar tidak diganggu selama pertunjukan berlangsung. Sesajen sebagai wujud syukur kepada Tuhan dan sebagai pengharapan agar pada saat pertunjukan senentiasa dilimpahkan pertolongan dan kemudahan. Adapun sesaji yang digunakan, diantaranya (1) Uba rampe takir, meliputi gula gimbal gula grinsing, empon, gantal (daun sirih yang ditali) dan kemenyan, (2) Kambil cengkir (kelapa muda), (3) gedhang raja, (4) kembang telon meliputi bunga melati, bunga kantil dan bunga.

Dalam sajian Ritual Obong Dupa, terdapat sebuah unsur penting dan tidak boleh ditinggalkan, yaitu penggunaan Gendhing Tolak Balak. Gendhing Tolak Balak difungsikan sebagai media penghantar antara manusia dengan alam gaib. Gending ini memiliki kedudukan yang tinggi, sehingga apabila di dalam pertunjukan kesenian Jaranan tidak menggunakan gending Tolak Balak, masyarakat percaya pertunjukan tidak akan berjalan dengan lancar dan musibah akan berdatangan.

\section{Gendhing Tolak Balak}

Gending Tolak Balak berawal dari seniman Tulungagung bernama Wagiran. Penciptaan Gendhing Tolak Balak berasal dari ide atau gagasan dalam diri Wagiran untuk membuat sebuah gending bernuansa sakral. Tahun 1990 bersamaan dengan pembuatan gending, Wagiran diberikan tawaran oleh anggota Jaranan Kuda Birawa untuk mengisi sebuah rekaman di Kota Nganjuk. Saat rekaman, Gendhing Tolak Balak masih berupa garapan sederhana. Setelah proses penciptaan gending, Wagiran kembali ke Tulungagung dan memiliki gagasan untuk mengembangkan Gendhing Tolak Balak di Kabupaten Tulungagung.

Gendhing Tolak Balak memiliki makna khusus. Tolak dalam bahasa Jawa diartikan sebagai nyingkirake, ngadohke, ngilangke adalah menyingkirkan, menjauhkan, dan menghilangkan. Kata Tolak memiliki makna luas tergantung dengan pemakaian. Bala diartikan malapetaka, bahaya atau bencana. Tolak Balak adalah segala macam upaya untuk menyingkirkan berbagai bahaya, hambatan, rintangan, godaan secara lahir dan batin.

Wagiran percaya kepada Tuhan, dan meyakini kepada leluhur mereka. Keseimbangan di antara kedua aspek terbentuk dengan baik. sesuai dengan pembentukan Gendhing Tolak Balak oleh Wagiran. Wagiran mengkaitkan dua aspek kehidupan, yaitu Tuhan Yang Maha Esa dan roh leluhur. Hubungan interaksi menjadikan Gendhing Tolak Balak memiliki makna atau ruh pada setiap sajian dan memberikan pengaruh baik dalam kesuksesan pertunjukan Kesenian Jaranan Kridha Budaya.

Gendhing Tolak Balak memiliki bentuk dan penyajian sederhana. Bentuk gending adalah srepegan, alur penyajian tidak menentu, yakni disesuaikan dengan penyajian ritual Obong Dupa. Durasi pada saat Ritual Obong Dupa kurang lebih lima sampai sepuluh menit. Durasi bisa lebih lama, karena banyak runtutan acara seperti mengumpulkan para gambuh di atas panggung dan mengumpulkan properti jaranan untuk diikutsertakan pada saat Ritual Obong Dupa.

Gendhing Tolak Balak memberikan pengaruh kepada Ritual Obong Dupa dan diyakini memiliki aksi-reaksi pada saat ritual. Awal mula gending terbentuk dimulai dari kebiasaan Tulungagung yaitu melakukan ritual khusus. Ritual diselenggarakan pada saat menjelang malam 1 suro, ritual di candi-candi dan tempat keramat di Tulungagung. Gendhing Tolak Balak tidak disajikan pada kesenian Jaranan, tetapi diadakan secara khusus dan setelah prosesi ritual terdapat 
pergelaran seni pertunjukkan rakyat, seperti seni karawitan, seni tari, ketoprak dan ludruk. Pada pertama kemunculan, Gendhing Tolak Balak dan Ritual Obong Dupa adalah dua komponen berdiri

Gendhing Tolak Balak dirujuk menjadi gending ritual pada kesenian Jaranan. Pengambilan gending menyebabkan keterkenalan pada Gendhing Tolak Balak dan terdengar hingga ke pelosokpelosok daerah, baik dalam daerah Tulungagung sendiri, dari luar daerah Tulungagung, seperti Trenggalek, Kediri dan Blitar. Karya Wagiran adalah Gendhing Tolak Balak dapat terkenal dan digunakan pada kesenian Jaranan Kridha Budaya.

Kariman memiliki tekad untuk mengambil Gendhing Tolak Balak pada Kesenian Jaranan di daerah-daerah lain, tanpa mengurangi nilai kesakralan dari gending. Nilai kesakralan dalam Gendhing Tolak Balak terletak pada cakepan dan frekuensi antar notasi, ditimbulkan dari iringan gending, dan disesuaikan dengan daya tangkap pendengar.

Suara dan musik dapat menggetarkan serta meresonan irama alamiah agar kondisi kesehatan kembali menjadi harmonis. Setiap sel di dalm tubuh manusia adalah resonator suara dan hidup dalam pola ritmis serta masing-masing organ memiliki siklus, pulsa dan nada musikal. Berbagai sistem dalam tubuh akan bereaksi terhadap getaran suara seperti yang terjadi pada mental, emosi, dan kesadaran spiritual seseorang (Djohan 2009, 278)

Perbedaan garap pada Gendhing Tolak Balak pada Kesenian Jaranan Kuda Birawa dengan Kesenian Jaranan Kridha Budaya, tidak memengaruhi nilai kesakralan dari gending. Masingmasing garapan memiliki nyawa atau ruh pada setiap sajian. Ruh gending berpengaruh kepada psikologis pendengar. Pelaku Kesenian Jaranan Tulungagung menyakini garap Srepegan menimbulkan kesan sakralitas dalam iringan sebuah ritual. Garap Lancaran diyakini sebagai komponen vital atau tidak boleh ditinggalkan atau diganti dengan gending lain pada Kesenian Jaranan Kridha Budaya. Keyakinan disesuaikan dengan kepercayaan masyarakat terhadap relasi dari kedua komponen, dan masyarakat meyakini atas pengaruh dari penggunaan Gendhing Tolak Balak pada Ritual Obong Dupa. Proses peengambilan gending berdasarkan alasan kuat, yaitu keyakinan kuat atas aksi-reaksi dari gending, dan menjadikan Gendhing Tolak Balak memiliki peranan penting dalam Ritual Obong Dupa.

\section{Garap Gendhing Tolak Balak}

Gendhing Tolak Balak memiliki garap khusus. Gendhing Tolak Balak berdiri sendiri dan tidak bisa diidentifikasi putaran sajian, disesuaikan dengan penyajian Ritual Obong Dupa. Ricikan penting dalam Gendhing Tolak Balak adalah ricikan kendang. Kendang di dalam sajiannya memiliki peran ganda, pada satu sisi kendang memimpin jalannya sajian pertunjukan, penguat aksen sekaligus sebagai pembentuk karakter sebuah gending berdasarkan garapnya. (Trustho 2005, 24)

Karakter gending sesuai dengan peranan kendang dalam menggugah rasa pendengar. Gendhing Tolak Balak memiliki karakteristik tegas dan tidak monoton pada satu garap. Ketegasan Gendhing Tolak Balak terlih at dari susunan notasi. Masing-masing notasi memiliki frekuensi pada setiap tabuhan. Penyajian dari Gendhing Tolak Balak terkesan disesuaikan dengan waktu dan kondisi. Awal pembukaan para gambuh menyiapkan ubarampe pada Ritual Obong Dupa, Gendhing Tolak Balak disajikan dengan nuansa ramai dan meriah, bertujuan untuk memberikan informasi pertunjukan segera dimulai. Gendhing Tolak Balak dimainkan dengan nada pelan dan memberikan nuansa sakral pada Ritual Obong Dupa, dipengaruhi oleh pembawaan pengrawit dalam mengkolaborasikan beragam garap dalam satu sajian gending. 


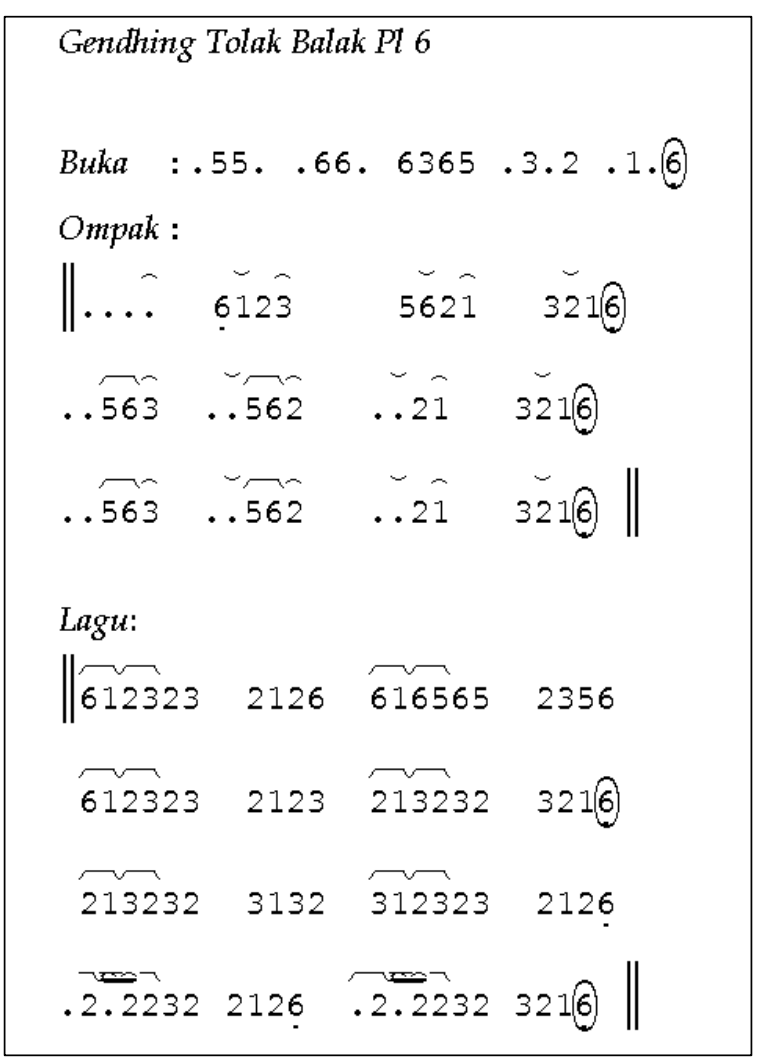

Gambar 1. Notasi Gendhing Tolak Balak yang digunakan di dalam pertunjukan Jaranan (Sumber: Rika Wahyuningtyas 2021)

Bentuk dan struktur gending adalah sebuah komponen penting dalam dunia karawitan. Pemahaman bentuk dan struktur gending bertujuan untuk memudahkan dalam memilih, menggarap dan menyajikan cengkok-cengkok, maupun wiledan dalam sebuah sajian karawitan. Terdapat unsur-unsur dalam menentukan bentuk dari sebuah gending, diantaranya (1) jumlah balungan dari setiap gongan, (2) letak tabuhan struktural, (3) cara pengkalimatan lagu dalam permainan ricikan garab atau vokal. Bentuk Gendhing Tolak Balak pada Kesenian Jaranan Krida Budaya adalah bentuk lancaran. Lancaran adalah jenis bentuk garap memiliki ukuran di bawah kethuk kalah. Ricikan Kempyang tidak digunakan. Gong digunakan adalah gong gede. Setiap gong, jumlah balungan dan kenong sudah ditentukan. (Martopangrawit 1972, 11)

Lancaran memiliki bentuk dan struktur sederhana. Kesederhanaan dilihat dari keajegan ira ma dan cara menabuh. Keajegan terlihat pada sabetan atau ketukan ritmis yang setiap gongan berisi 16 sabetan. Endraswara menjelaskan, lancaran dibagi menjadi 2 bentuk, diantaranya lancaran lamba atau lancaran nibani dan lancaran mlaku. (Endraswara 2008, 87) Bentuk pada Gendhing Tolak Balak dalam Kesenian Jaranan Kridha Budaya adalah bentuk lancaran mlaku, yaitu terdiri atas 16 sabetan balungan. Penggunaan bentuk lancaran irama mlaku pada Gendhing Tolak Balak memiliki pengaruh dalam gending Tolak Balak. Tidak semua lancaran menggunakan lagu atau tembang, dalam penyajian lancaran irama mlaku disertai dengan tembang atau lagu, bertujuan agar antara tembang dan iringan lebih banyak kesesuaian.

Lancaran digunakan pada bagian ompak, setelah rambahan kedua atau masuk lagu terdapat peralihan ke garap pematut, ditandai dengan garap kendang menggunakan sekaran pematut. Pematut adalah kendangan pada gending-gending belum memiliki aturan penyajian kendangan secara ketat, berdasarkan lagu dan tafsir pengendang sendiri dengan menggunakan vokabuler kendangan atau dengan membuat sekaran kendangan baru dapat berubah sesuai dengan kebutuhan. Kendhang disebut ricikan pamurba irama, artinya semua pergantian irama dan gending ditentukan oleh pengendang, tetapi pengendang tidak berarti bebas sama sekali, karena masih terikat oleh peraturan-peraturan dalam tata gending, tata irama dan laya. (Martopangrawit 1972, 1) 


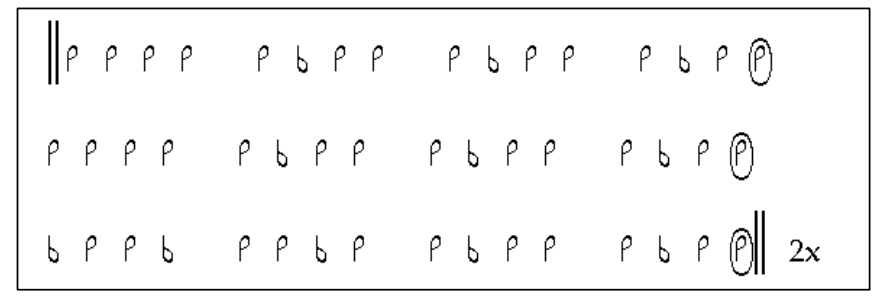

Gambar 2. Notasi Kendangan Lancaran Tolak Balak Pelog Nem (Sumber: Rika Wahyuningtyas 2021) pematut

Setelah gong ke dua pada kendangan salahan gatra kedua terdapat peralihan ke kendang

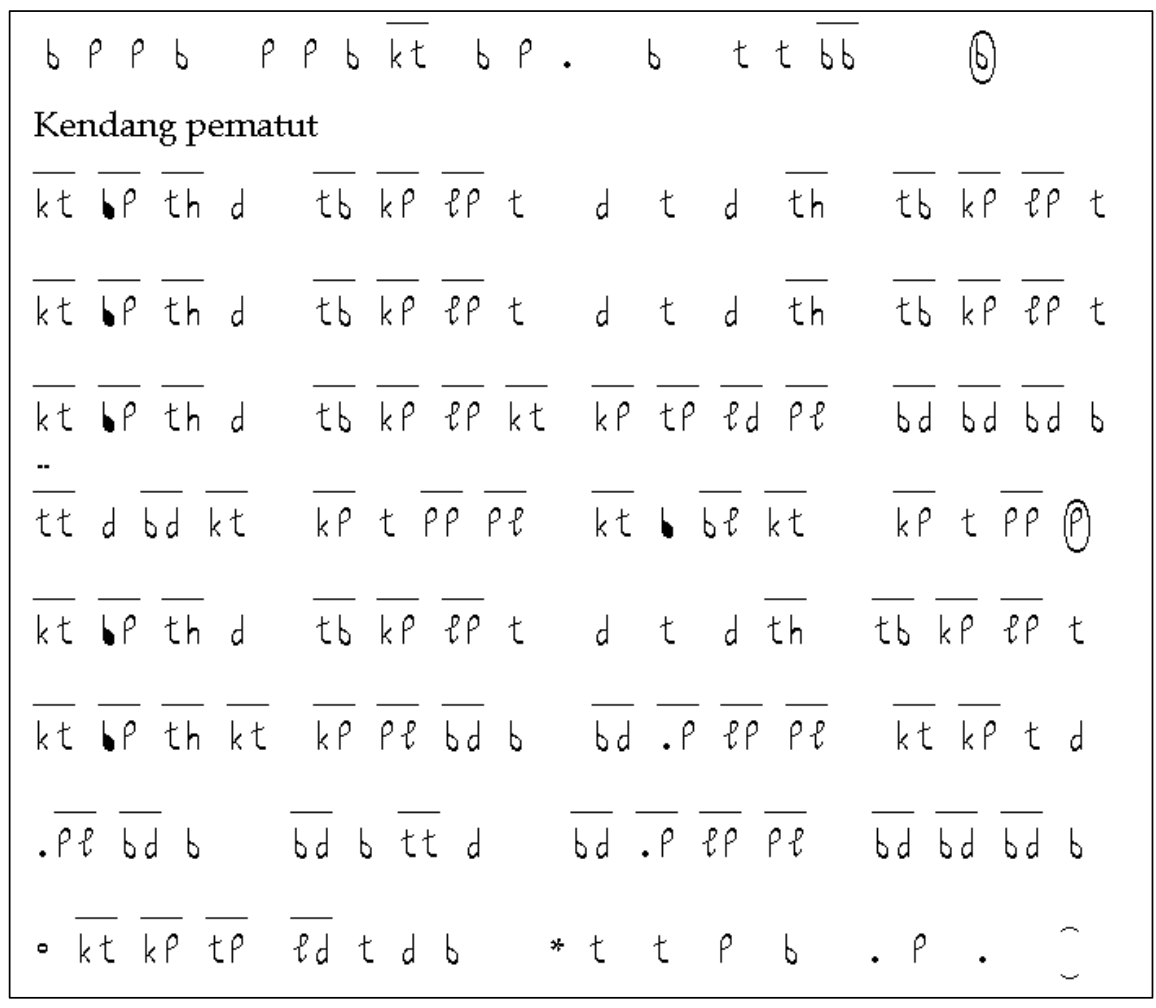

Gambar 3. Notasi Kendangan Pematut Lancaran Tolak Balak Pelog Nem (Sumber: Rika Wahyuningtyas 2021)

Gendhing Tolak Balak memiliki struktur balungan gending antara diantaranya buka dan batang tubuh (bagian pokok). Ricikan yang berperan sebagai pembuka dalam Gendhing Tolak Balak adalah bonang. Pemilihan ricikan bonang digunakan sebagai pembuka gending, karena disesuaikan dengan jenis gending. Jenis gending pada Gendhing Tolak Balak adalah lancaran. Saat buka gending, semua ricikan harus memusatkan perhatian kepada bonang.

Buka. .55. .66. $6365 \cdot 3.2 \cdot 1.6$

Gambar 4. Notasi buka pada Gendhing Lancaran Tolak Balak
(Sumber: Rika Wahyuningtyas 2021)

Bagian pokok adalah bagian gending setelah buka dan dilakukan secara berulang. Bagian pokok pada Gendhing Tolak Balak meliputi bagian ompak dan vokal. Bagian pokok adalah bagian penting, pada bagian pokok menunjukkan identitas Gendhing Tolak Balak. Struktur gending masih 
seperti struktur gending lancaran, adapun perbedaan terletak pada alur sajian. Berikut struktur pada Lancaran Tolak Balak

\begin{tabular}{|c|c|c|c|c|c|c|c|c|c|c|c|c|c|c|c|}
\hline & & + & - & + & $\smile$ & + & - & + & $\sim$ & + & - & + & $\sim$ & + & \\
\hline - & $\cdot$ & • & - & • & $\cdot$ & • & - & • & • & • & • & - & - & $\cdot$ & (.) \\
\hline & $\sim$ & + & - & + & - & + & - & + & $\mathcal{U}$ & + & - & + & $\mathcal{C}$ & + & \\
\hline - & • & • & - & • & - & • & - & $\cdot$ & $\cdot$ & • & • & • & • & • & $\bullet$ \\
\hline & $\sim$ & + & - & + & 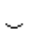 & + & - & + & U & + & - & + & $\sim$ & + & \\
\hline - & $\cdot$ & • & - & $\cdot$ & - & • & $\cdot$ & $\cdot$ & $\cdot$ & $\cdot$ & • & • & - & • & 6 \\
\hline
\end{tabular}

Gambar 5. Struktur Gendhing Lancaran Tolak Balak

(Sumber: Rika Wahyuningtyas 2021)

\section{E. Fungsi Ritual Gendhing Tolak Balak}

Fungsi ritual dari Gendhing Tolak Balak berkaitan erat dengan tingkat kesakralan. Secara etimologis, kata "sakral" dapat disamakan dengan sacred (dalam Bahasa Inggris) yang berarti suci, keramat. (Depdiknas 2001) Dalam Bahasa Jawa istilah "sakral" ini dapat disamakan dengan suci, kramat, wingit, angker dan gaib. (Suyanto 2018, 50) Sakral dikaitkan dengan kepercayaan adanya danyang atau roh penunggu suatu tempat. Sakralitas dalam Kesenian Jaranan direalisasikan berdasarkan pengaruh dari hubungan antara pelaku dengan danyang. Pengaruh dapat berupa rangsangan dalam diri pelaku (merinding) ketika prosesi ritual, maupun keyakinan dalam diri pelaku terhadap suatu kejadian di masa lampau. Untuk mencapai sakralitas dalam prosesi Ritual Obong Dupa, terdapat faktor-fator pendukung, yaitu (1) penentuan saat yang tepat, (2) pelaksanaan sakralisasi dan, (3) perhitungan durasi yang dibutuhkan.

Gendhing Tolak Balak memiliki fungsi penting dalam penyajian Ritual Obong Dupa. Untuk menjelaskan hubungan fungsi gending dalam konteks sebagai pendukung sakralitas Ritual Obong Dupa dilakukan tiga obyek pengamatan pada kelompok Kesenian Jaranan Kridha Budaya. Ketiga obyek yaitu mediator, penyaji, dan anggota kelompok lain terlibat dalam prosesi Ritual Obong Dupa. Mediator menjadi pemimpin jalan ritual dan sebagai sosok sentral untuk memahami kontruksi hubungan gending dengan ritual. Mediator dalam Kesenian Jaranan Kridha Budaya adalah adalah tetua atau gambuh, yaitu seseorang tetua atau diberi tanggung jawab khusus sebagai pemimpin pertunjukan atau grup Jaranan sebagai media atau pawang untuk menghubungkan antara dunia manusia dengan alam gaib. Pawang memiliki keutamaan khusus, ia terlahir sebagai indigo atau bahkan sengaja belajar ilmu gaib untuk memudahkan interaksi dengan roh gaib.

Keselarasan antara manusia dengan roh gaib akan memudahkan pencapaian tujuan dalam sebuah pertunjukan. Penyaji adalah anggota kelompok dengan memainkan instrument dalam sajian gending dan melakukan prosesi ritual. Penyaji memiliki peranan dalam penyajian gending. Iringan dimainkan secara tidak langsung bertujuan untuk mengiringi jalan Ritual Obong Dupa dan sebagai penghantar sakralitas dari Gendhing Tolak Balak. Anggota lain dalam prosesi adalah anggota kelompok Kesenian Jaranan Kridha Budaya atau penonton dalam pertunjukan, dan tidak berperan sebagai mediator maupun penyaji, tetapi dalam prosesi yang berlangsung anggota itu hadir dan berkhidmat mengikuti prosesi ritual.

Ritual Obong Dupa tidak terlepas dari faktor-faktor pendukung kesakralan. Baik faktor internal maupun faktor eksternal. Faktor internal berasal dari unsur pembangun ritual. Faktor eksternal adalah faktor berasal dari luar unsur pembangun sebuah ritual, seperti Gendhing Tolak Balak. Ritual dan gending adalah dua komponen berbeda dan masing-masing memiliki unsur pembangun. Gending adalah pranata luar sekaligus menjadi faktor pelengkap tersajinya Ritual Obong Dupa dan sebab muncul kesan sakral. Faktor internal dibangun atas dasar unsur pembangun 
sebuah ritual, seperti mantra, sesaji, dan gambuh atau pawang. Faktor-faktor menjadi sebab suatu ritual memiliki makna sakral pada awal pembukaan Kesenian Jaranan Kridha Budaya.

Sejarah prosesi Ritual Tolak Balak ditujukan untuk mendekatkan diri pada sang pencipta. Ritual dengan memainkan gending diiringi oleh gamelan ditunjukkan sebagai wujud upaya menjalin komunikasi dengan Tuhan sebagai penjabaran atas jalinan hubungan antara ciptaan dengan Penciptanya. Kegiatan memainkan gamelan dijelaskan sebagai kontruksi dalam mengingat dan merenungi keberadaan Tuhan. Segenap perilaku dalam memainkan gamelan, penyaji menghadirkan diri pada ruang khusus untuk menyampaikan ungkap perasaan kepada Sang Pencipta. Pelaku menyadari bahwa penguasa alam raya beserta isinya adalah Tuhan Yang Maha Esa. Keyakinan dengan jelas menerangkan alasan mengapa masyarakat Kesenian Jaranan Kridha Budaya mengawali pertunjukan dengan berdoa kepada Allah. Pelaku mempercayai bahwa setiap tempat memiliki penunggu masing-masing, ada yang jahat dan baik. Danyang baik biasa bertugas untuk menjaga keselamatan desa dan penduduk desa, sedang danyang jahat adalah mereka mengganggu keselamatan desa dan warga desa. Masyarakat Kesenian Jaranan Kridha Budaya meyakini, untuk mendapatkan kehidupan baik, mereka harus selalu berdoa dan memuji kepada Tuhan pada setiap keadaan, sehingga dengan begitu, ia akan terlindungi dari gangguan-gangguan roh-roh jahat dan gangguan dari manusia.

Gending Tolak Balak sebagai perwujudan permohonan seorang manusia kepada Tuhan sang pencipta, agar dilindungi dari segala macam marabahaya. Pelaku meyakini, bahwa apabila sesuatu dikemas dengan baik akan cepat tersampai kepada yang dituju, seperti dengan mengemas doa ke dalam sebuah gending akan memiliki nilai kekhusyukan di dalam gending. Fenomena tidak terlepas dari sistem keyakinan manusia, mereka meyakini bahwa doa hanya bisa dilakukan pada waktu-waktu tertentu, tetapi ada pula masyarakat berkeyakinan, bahwa dengan melatunkan sebuah syair atau lagu dapat menambah kekhusyukan dalam doa. Pelaku hanya menjalankan sebab-sebab untuk mendatangkan manfaat bagi kelancaran pertunjukan, salah satun contoh adalah menggelar prosesi Ritual Obong Dupa.

Gendhing Tolak Balak sebagai komponen baku dan tetap diyakini sebagai gending sakral hingga sekarang. Gendhing Tolak Balak berperan dalam menjaga keseimbangan hidup. Keseimbangan berkaitan dengan hubungan manusia dan roh gaib.

Pemilihan tempat adalah langkah penting untuk mewujudkan kelancaran pertunjukan. Tempat akan menjadi ruang dimana para gambuh berinteraksi dengan Tuhan dan alam gaib. Pemilihan tempat berkaitan dengan danyang atau roh penunggu tempat. Danyang diyakini sebagai roh atau arwah memiliki tugas untuk menunggu suatu tempat. Masyarakat kesenian Jaranan Kridha Budaya mengibaratkan danyang sebagai tuan rumah, ia memiliki hak dan kekuasaan atas tempat mereka. Ketika mengunjungi rumah orang lain, harus mengetahui adab-adab agar diterima baik oleh tuan rumah. Begitupula seharusnya diperhatikan oleh seorang pelaku kesenian, yakni menjaga etika dan sopan santun ketika akan menggelar seni pertunjukan di suatu tempat. Etika dan sopan santun adalah kelengkapan atau prasyarat harus dipenuhi oleh pelaku kesenian, diantaranya, menyiapkan sesajen dengan ubarampe, dan pemakaian Gendhing Tolak Balak pada Ritual Obong Dupa. Gendhing Tolak Balak menjadi syarat penting oleh seorang pelaku kesenian, yaitu sebuah permintaan tuan rumah harus dipenuhi apabila ia ingin menggunakan rumah sebagai tempat pertunjukan.

\section{Kesimpulan}

Pada Kesenian Jaranan Kridha Budaya, gending menjadi unsur penting dalam pertunjukan. Penggunaan gending disesuaikan berdasarkan fungsi dan tujuan. Gending berdasarkan fungsi seperti pada gending tarian yang digunakan untuk mengiringi gerakan tarian, sedangkan gending berdasarkan tujuan seperti Gendhing Tolak Balak pada Ritual Obong Dupa yang menjadi unsur wajib dan tidak boleh diganti dengan gending lain. Gendhing Tolak Balak hanya disajikan selama prosesi 
ritual dan tidak dimainkan pada bagian lain. Gendhing Tolak Balak digolongkan menjadi gending baku yakni gending tidak boleh diganti atau ditiadakan. Fenomena berkaitan dengan keyakinan dari pelaku kesenian. Pada Kesenian Jaranan Kridha Budaya, pelaku meyakini bahwa Gendhing Tolak Balak memiliki unsur magis dan dapat menghantarkan seseorang kepada Tuhan. Gending ini digunakan sebagai pengiring pada Ritual Obong Dupa. Korelasi antara Gendhing Tolak Balak dan Ritual Obong Dupa yang disertai dengan keyakinan dari pelaku, membentuk sebuah kepercayaan bahwa keberhasilan sebuah usaha sangat dipengaruhi oleh kekuatan magis di luar kemampuan manusia. Gendhing Tolak Balak digunakan sebagai gending baku yang dimaknai sebagai sarana untuk menyampaikan permohonan, ataupun sebagai bentuk interaksi yang dilakukan secara tidak langsung kepada Tuhan dan danyang penunggu suatu tempat. Ditinjau dari segi fungsi, Gendhing Tolak Balak dan Ritual Obong Dupa memiliki peran yang sama dalam Kesenian Jaranan Kridha Budaya. Salah satunya adalah sebagai sarana untuk berdoa kepada Allah agar diberikan kelancaran dan kemudahan selama pertujukan berlangsung. Gendhing Tolak Balak tersusun dari beberapa unitunit berupa tempo, irama dan dinamika. Hubungan timbal balik dan saling menguatkan dari beberapa unsur menjadikan sebuah kekuatan dalam mewujudkan tercapainya tujuan fungsi musikal.

\section{Daftar Pustaka}

Agustina, Viesta, and Muhammad Nur Salim. 2020. “Fungsi Musik Dalam Ritual Tiban Di Desa Purwokerto Kecamatan Ngadiluwih Kabupaten Kediri." Keteg: Jurnal Pengetahuan, Pemikiran Dan Kajian Tentang Bunyi 20 (1): 14-28. https://doi.org/10.33153/keteg.v20i1.3563.

Depdiknas. 2001. Kamus Besar Bahasa Indonesia. Jakarta: Balai Pustaka.

Djohan. 2009. Psikologi Musik. Yogyakarta: Best Publisher.

Endraswara, Suwardi. 2003. Metodologi Penelitian Sastra. Yogyakarta: Pustaka Widyatama.

- - - 2008. Metodologi Penelitian Psikologi Sastra. Yogyakarta: Media Pressindo.

Fitriasari, Rr. Paramitha Dyah, Timbul Haryono, G.R. Lono Lastoro Simatupang, and Irwan Abdullah. 2012. "Ritual Sebagai Media Transmisi Kreativitas Seni Di Lereng Gunung Merbabu." Kawistara 2 (1): 25-35.

Keesing, Roger M. 1981. Antropologi Budaya. Jakarta: Erlangga.

Koentjaraningrat. 1990. Pengantar Ilmu Antropologi. Jakarta: Rineka Cipta.

- - - 1997. Pengantar Antropologi (Pokok-Pokok Etnografi II). Jakarta: PT Rineka Cipta.

Martopangrawit. 1972. Pengetahuan Karawitan I. Surakarta: ASKI.

Merriam, Allan P. 1964. The Anthropology of Music. Evanston, Illinois: Northwestern University Press.

Moleong, Lexy J. 2014. Metode Penelitian Kualitatif. Bandung: PT. Remaja Rosdakarya.

Prastowo, Andi. 2011. Metode Penelitian Kualitatif Dalam Perspektif Rancangan Penelitian. Yogyakarta: 


\section{Ar-Ruzz Media.}

Ratna, Nyoman Kutha. 2010. Metodologi Penelitian: Kajian Budaya Dan Ilmu Sosial Humaniora Pada Umumnya. Yogyakarta: Pustaka Pelajar.

Schechner, Richard. 2002. Performance Studies An Introduction. London and New York: Routledge.

Soemaryatmi. 2012. “Dampak Akulturasi Budaya Pada Kesenian Rakyat.” Panggung: Jurnal Seni $\mathcal{E}$ Budaya 22 (1): 25-36.

Spradley, James P. 2007. Metode Etnografi. Yogyakarta: Tiara Wacana.

Sumardjo, Jacob. 2006. Estetika Paradoks. Bandung: Sunan Ambu Press.

Suyanto. 2018. "Makna 'Sakral' Dalam Tradisi Budaya Jawa." Lakon, Jurnal Pengkajian E Penciptaan Wayang XV (2): 69-75.

Trustho. 2005. Kendang Dalam Tradisi Tari Jawa. Surakarta: STSI Press.

Turner, V. 1969. The Ritual Process. London: Routledge and Kegan Paul. 